\title{
Effectiveness of Counseling With Cartoon Animation Audio Visual Methods In Increasing Tooth Brushing Knowledge Children Ages 10-12 Years
}

\author{
Ayub Irmadani Anwar ${ }^{1}$, Nursyamsi ${ }^{2}$, Andi Zulkifli ${ }^{3}$, \\ Aminuddin Syam ${ }^{4}$, \\ \{ayubanwar_mks@yahoo.com ${ }^{1}$, nursyamsi4874@gmail.com ${ }^{2}$, zulkifliabdullah@yahoo.com ${ }^{3}$, \\ amingzuh@gmail.com ${ }^{4}$ \} \\ Doctoral Student, Faculty of Public Health, Hasanuddin University, Indonesia ${ }^{1,2}$ \\ Epidemiology Department, Faculty of Public Health, Hasanuddin University, Indonesia ${ }^{3}$ \\ Nutrition Science Study Program, Faculty of Public Health, Hasanuddin University, Indonesia ${ }^{4}$
}

\begin{abstract}
Dental and oral hygiene is a public health problem that requires comprehensive treatment. Through the Counseling program, it is expected to increase knowledge and raise awareness of the importance of maintaining dental and oral health. The objective of this study is to find out the effectiveness of Counseling with cartoon animation audiovisual method in increasing the knowledge of brushing teeth. Research method with pre-experiment research type, one group pre-test post-test design with a cross-sectional approach counseling the level of knowledge of brushing teeth using audio-visual methods with cartoon animation videos. This research was conducted on children aged ten to twelve years at Toddopuli Superior Primary School in Makassar City, Indonesia. The results of this study show the average value of subjects before and after Counseling is in a good category. Counseling is in the category of good and less knowledge. Fifteen or eighteen percent of children are in the category of a sufficient level of knowledge. After Counseling, there are eighty-two or ninety-eight point eight percent of children are in the category of good knowledge level. There is only one or one point two percent of children in the sufficient category, and none in the category lack of knowledge. The conclusion, Counseling with cartoon animation audiovisual method effectively increases the knowledge of brushing teeth of children aged ten to twelve years.
\end{abstract}

Keywords: Tooth brushing, knowledge, attitude, animated cartoon audiovisuals

\section{Introduction}

Dental and oral health is an important part of achieving general health and quality of life. Maintenance of dental and oral hygiene is an important factor in achieving dental health, which can be done by brushing teeth $[1,2]$.

According to the World Health Organization (WHO), there are 60-90\% of school children worldwide who experience tooth decay. Basic health research results in Indonesia 2013, as many as $25.9 \%$ of Indonesia's population have dental and mouth problems, with South Sulawesi province as the province with the biggest dental and oral problem $(36,2 \%)$. Also, from 10-14-year-olds people who have a habit of daily tooth brushing, there is only $1.7 \%$ who 
brush their teeth correctly (after breakfast and before bed). This may be caused by the lack of knowledge and public awareness of dental and oral hygiene [1], [2], [3],[4]. Therefore, it is necessary to improve the dental and oral health, one of them by oral and dental health education in the form of counseling.

Dental and oral health education is all efforts or activities to influence a person to behave well in maintaining oral health, as well as raising public awareness of oral health and giving an understanding of ways to maintain oral health. One example is the knowledge of tooth brushing. The child is expected to know the correct type of toothbrush, correct brushing method, as well as the proper time and brushing frequency [2],[5]. The significant effects of dental caries if untreated not limited only to the mastication function but also affect speech, smile, and psychosocial environment and the quality of life [6].

Dental and oral health counseling should be given to school-aged children. Through the counseling program is expected to increase the knowledge and awareness of children about the importance of maintaining oral health and can participate actively in improving self-care efforts. Also, with counseling, a person can make a self-effort in the prevention of dental and oral disease. The delivery of counseling materials to the target other than the method to be used is also influenced by the presence or absence of aids or supporting media for delivery. Supporting aids or media are very important when used for counseling because the tools are used by educators in delivering educational or teaching materials. Educational media in improving dental and oral health in children such as multimedia, especially animated cartoons that have been explored widely can be used as teaching aids. Studies report that teaching by using animation techniques will improve students' academic performance [2], [7].

Early primary school students need to be educated to be able to maintain the health of their teeth: Class V and VI students aged between 10-12 years. At the age of 10-12 years, the child enters the beginning of the fixed tooth phase; although there is still a shift from the deciduous to permanent teeth, there are many permanent teeth grow. At that age can already get an understanding and can explain about something realistically. Also, at the age of 10-12 years already can be given responsibility for the action of brushing teeth. At the age of 10-12 years have been able to do brushing teeth systematically when compared with the age group below. Because of that, dental health should be maintained early so that children can have good permanent teeth [8].

Knowledge is the result of human sensing or the result of a person knowing the object through his or her senses. Much of a person's knowledge is acquired through the sense of sight (eye) and the sense of hearing (ear). A person's knowledge of objects has different intensities or levels [9].

Brushing teeth is cleaning teeth from food scraps, bacteria, and plaque. Teeth brushing knowledge includes how to brush your teeth properly and correctly, which is the implementation of time, use of tools, and the right way to clean teeth. The potential for good and correct brushing is an important factor for maintaining dental and oral health. Successful maintenance of dental and oral health is greatly influenced by factors of use of tools, methods of brushing teeth, as well as the frequency and timing of proper brushing [10].

Dental health counseling is a planned and directed effort to create a person or group of people want to change old behavior, which is less profitable, to be more profitable. Through dental health counseling, it is expected that it can increase public knowledge and awareness of the importance of maintaining dental and oral health. The selection of the right method in the process of delivering counseling material is very helpful in achieving efforts to change target behavior. Video media is one type of audiovisual media that relies on the senses of sight and hearing. Counseling using cartoon animated videos is one method of audiovisual counseling 
that uses computer media, LCD, and projector to deliver counseling material to counseling participants. This counseling requires the ability of the senses of sight and hearing (eyes and ears) to receive information on the knowledge provided. The benefits of video media in learning include attracting and directing students' attention to concentrate on the content of the lesson, can be seen from the level of emotional involvement and attitudes of students when listening to the impressions of subject matter accompanied by visualization, helping understanding and memorizing of material content for students weak in reading [5] [10].

The selection of audiovisual media in an informative cartoon can be well received by the respondents. It offers an exciting and non-monotonous education, featuring motion, pictures, and sounds, while the print media displays the writings and sounds of educators so make them seem formal and boring [11]

The purpose of this research is to know the effectiveness of counseling with the audiovisual method in improving knowledge of tooth brushing of children aged 10-12 years.

\section{Research Methods}

This type of research is pre-experiment, one group pre-test post-test design. The research approach used is cross-sectional. Tooth brushing knowledge counseling using the audio-visual method with animated cartoon video. This study was conducted on children aged 10-12 years in Toddopuli Superior Primary School, city of Makassar Indonesia, in November 2017. Research subjects were 82 children. This study has received ethical recommendations by the Health and Dental Hospital research committee of the Faculty of Dentistry, Hasanuddin University.

Assessment of the knowledge level of tooth brushing research subjects is based on the choice of answers to the questionnaire question. Each correct answer is given a score of 1, while the wrong answer is given a score of 0 . Then score is added and divided by the number of questions and multiplied by $100 \%$. Criteria of knowledge assessment $\leq 50 \%$ are less knowledge, $50 \%-75 \%$ is medium knowledge, $\geq 75 \%$ is good knowledge.

The effectiveness of increased brushing knowledge was measured by comparing the mean test scores pre and post-test counseling, using $\mathrm{T}$ paired analysis. If the p-value $<0.05$, there is a statistically significant increase in knowledge and means that the counseling method used effectively improves the knowledge of the subject's toothbrushing. Pre-tests were carried out before counseling, and post-tests were given after counseling.

\section{Result}

The research begins with giving directions to the subject about the technical procedures of the research conducted, then distributing the questionnaires sheet as a tooth brushing test before being given audio-visual counseling (pre-test). Next, they are given a visual audio counseling by playing animated video on how to maintain dental health with duration \pm 7 minutes and just once. Then the subject was distributed a questionnaire sheet as a knowledge post-test being given counseling (post-test). 
Table 1. Distribution of the number of subjects by gender and age of children aged 10-12 in Toddopuli Superior Primary School city of Makassar, Indonesia

\begin{tabular}{ccc}
\hline Subject characteristics & N & \% \\
\hline Gender & 38 & 46.3 \\
Male & 44 & 53.7 \\
Female & 82 & 100 \\
Total & & \\
Age & 26 & 31.7 \\
10 years & 38 & 46.3 \\
11 years & 18 & 22 \\
12 years & 82 & 100 \\
Total & & \\
\hline
\end{tabular}

Table 1 shows the distribution of the number of subjects based on the characteristics of gender and age. Subjects consisted of 38 male and 44 female children. The subject age range is 10-12 years old. Age 11 years is the age with the highest number of subjects, which is as many as 38 children.

Table 2. Distribution of the number of subjects at the level of brushing knowledge pre and post-test given audio-visual method counseling of children aged 10-12 years in Toddopuli Superior Primary School city of Makassar, Indonesia

\begin{tabular}{ccccc}
\hline \multirow{2}{*}{ Knowledge level } & \multicolumn{2}{c}{ Pre } & \multicolumn{2}{c}{ Post } \\
\cline { 2 - 5 } & $\mathbf{N}$ & $\boldsymbol{N}$ & 0 & $\%$ \\
\hline Less & 1 & 1.2 & 1 & 0 \\
Medium & 15 & 18.3 & 81 & 98.2 \\
Good & 66 & 80.5 & 82 & 100 \\
Total & 82 & 100 & & N \\
\hline
\end{tabular}

Table 2 shows the level of knowledge of brushing pre and post-test being given counseling with audio-visual methods. Before the counseling, there were $66(80.5 \%)$ children in the category of good knowledge level and only 1(1.2\%) of children at the level of less knowledge. A total of $15(18.3 \%)$ children are in the category of medium level of knowledge. Post-test counseling, there were $82(98,8 \%)$ children in good knowledge level category. There are only $1(1.2 \%)$ children in the medium category, and none is in the category of less knowledge level. It can be concluded that there is a change in the level of knowledge of tooth brushing on the subject post-test being given counseling with audio-visual method. These changes were subsequently tested statistically using paired T-test with $\alpha=0.05$. The value tested is the average increase in the value of the test subjects obtained from the reduction of the average value of the pre and post-test being given counseling. 
Table 3. Mean score of pre and post-test gave audio-visual counseling method of 10-12-yearold child in Toddopuli Superior Primary School of Makassar city, Indonesia.

\begin{tabular}{llll}
\hline & Mean & N & p* \\
\hline Pre & $82.5 \%$ & 82 & \\
Post & $91.8 \%$ & 82 & \\
Increase & $9.3 \%$ & 82 & 0,000 \\
\hline
\end{tabular}

*T-test (confidence interval/CI 95\%)

The average value of the subject pre-test counseling was $82.5 \%$ or was in a good category. While the average value post-test counseling increased to $91.8 \%$, which is also in the good category, with an average increase of 9.3\% (Table 3). T-paired T-test results obtained p-value $=0,000$, which means that there is a statistically significant difference in test values pre and post-test the audio visual counseling method.

\subsection{Discussion}

The level of knowledge of tooth brushing of children aged 10-12 years in Toddopuli Superior Primary School city of Makassar, Indonesia pre-test being given counseling is mostly in the good category, that is 66 children $(80.5 \%)$. There are 14 children $(18.3 \%)$ are in the medium category, and only $1(1.2 \%)$ children are in the less category. These results illustrate the average level of knowledge of tooth brushing of children aged 10-12 years in Toddopuli Superior Primary School city of Makassar, Indonesia, before being given counseling is good. This can be caused by the condition of the school, which is a superior primary school, with the quality system, educators, and learners better than non-superior schools. In general, superior school students have a higher level of intellectual intelligence than non-superior school students (regular). The theory expressed by Ginanjar (2003) in Aziz R. (2006) that intellectual intelligence is needed to overcome cognitive (knowledge) problems [12].

Thus it can lead to the average level of knowledge of the subject's tooth brushing before being given counseling is in a good category. This is supported by research conducted by Swastiningtyas S. (2013), which indicates that there is a significant difference between superior grade dental knowledge and regular grade dental knowledge [13].

After being given counseling, the number of subjects who are in the knowledge level of good toothbrushing is increased to 82 children $(98.8 \%)$, and the remaining $1(1.2 \%)$ of the children are in the medium category. This indicates a change in the level of knowledge of tooth brushing on the subject after being given counseling with audio-visual methods.

Based on the average value of pre-test and post-test counseling, that is $82,5 \%$ and $91.8 \%$; it is known the difference of the mean value of pre-test and post-test counseling is equal to 9.3\%. T-paired T-test results obtained p-value $=0,000$, which means that there is a statistically significant difference in the value of the knowledge pre-test and post-test the audiovisual counseling methods. Thus, it can be concluded that effective audio-visual counseling improves knowledge of toothbrush age of the 10-12-year-old child in Toddopuli Superior Primary School city of Makassar, Indonesia. This is similar to the research by Prasko (2016) [5], which suggests that counseling with the audio-visual method is effective for use in improving teeth brushing knowledge in primary school children. 
The results of this study are supported by Shah N. (2018) [14], which states that video media can be an effective tool in improving knowledge about oral health in hospital environments. Yanti GN. (2012) [15] shows that counseling with a cartoon video playback method effectively improves knowledge score in second-grade students of Bodhicitta Medan primary School. This study was also supported by Andriany (2016) [2] research which revealed that the knowledge of dental and oral health of grade V students Primary School 24 Banda Aceh, Indonesia after being given counseling with cartoon animation better than before given counseling. Also, there are studies conducted by Nurfalah A. (2014)[5] which also shows that the effective video method improves the knowledge of the dental brushing of 9-12year-olds at Keraton 7 Primary School Martapura, Indonesia.

Counseling using cartoon video is one of the audiovisual counseling method using computer media, LCD, and projector to deliver counseling materials to counseling participants. This counseling requires the ability of the sense of sight and hearing (eyes and ears) to receive knowledge information. Notoatmodjo in Hastuti S. (2010) [16] reveals that knowledge is derived from the sensing results of a particular object, and much of human knowledge is obtained through the eyes and ears. This audiovisual method has also proven to be effective in increasing knowledge and lowering oral hygiene score in deaf children [17].

The use of audiovisual aids in science has proven to be an effective way to communicate ideas and concepts of knowledge to students. Some literature has also determined that audiovisual aids have improved student performance in science, especially in students with special needs and slow learners. Animated learning is an effective learning medium that teachers can use to provide students with learning experiences of science [18].

Researchers suspect the influence of health education through audiovisual methods may be influenced by the nature of cartoon media favored by children because it is interesting. Davis (2011) [19] reveals that media that involves more senses is greater than the written media. The use of video media in learning can provide a complete learning experience, clear, varied, interesting, and fun. [20] Kurt Lewis's theory also states behavioral changes occur because of encouragement or stimuli in the form of counseling or information. [21] According to Mills and Mc. Mullan (2009) that the presentation of colorful images and words in a tooth brushing video given to a child also affects increasing knowledge, where color strongly affects short-term memory and visual attention [22].

Shah and Khan have stated that the attraction of animated video on the children (student) result in increased attention toward the information given by animation [23]. Our finding shows that both methods have advantages and disadvantages; one of the advantages of the animation method its take less time to educate the children and deliver the information. The animation method requires less effort in the explanation of oral health education comparing to the conventional method. Sinor, in his study, found that the animation medium was more efficient and sustainable in delivering oral health education compared to the conventional method [24].

One of the limitations of this study that lack of the interval between the conventional and animated oral health education and the test of the perception throw the questionnaire, a difficulty in achieving standardization in the conventional method create bias issue problem. 


\section{Conclusion}

Audiovisual counseling with cartoon animation audiovisual methods by using effective animated video enhances knowledge of toothbrushing of 10-12-year-olds in Toddopuli Superior Primary School city of Makassar, Indonesia.

\section{References}

[1] World Health Organization (WHO). Health topics: oral health (2002)

[2] Andriany P., Novita CF., Aqmaliya S., Comparison of media effectiveness of poster and cartoon animation on tooth health knowledge. J. Syiah Kuala Dent Soc. Vol 1.pp.65-70 (2016)

[3] Agency for Health Research and Development RI.: Basic Health Research Results Report RI.Vol.7.pp.111 (2013)

[4] Ministry of Health RI.: Data and information Center: Info DATIN Teeth and Mouth. pp.1-4 (2014)

[5] Nurfalah A, Yuniarrahmah E, Aspriyanto D. Research report: effectiveness of demonstration methods and video methods on dental brush knowledge in children aged 9-12 years at SDN Keraton 7 Martapura.Dentino J Ked Gigi.Vol.2.pp.144-8 (2014)

[6] Mathur VP, Dhillon JK. Dental caries: A disease which needs attention. Indian J Pediatr Vol.85.pp.202-206 (2018)

[7] Prasko, Sutomo B, Santoso B. Illumination of audio visual methods and demonstrations of brushing knowledge in primary school children. J Kes Gigi Vol.3.pp.53-56 (2016)

[8] Arianto, Shaluhiyah Z, Nugraha P. Behavior of brushing teeth on elementary school students of class V and VI in Sumberejo Subdistrict. J Promosi Kes Indo:Vol.9.pp.29 (2014)

[9] Purwoko: Relationship of knowledge and attitude with dental health status in elementary school age children in working area of Puskesmas Sawit I (Thesis). Sebelas Maret University. Indonesian pp.3440 (2011)

[10] Putriani G. : Improvement of self-improvement learning efforts to brush teeth through animated video in children tunagrahita category while in grade IV SDLB SLB Negeri Pembina Yogyakarta (thesis). Yogyakarta State University pp.33-50 (2016)

[11] Puspita C.S.H.J., Badi'ah A: Effect Of Health Education Through Visual Median On The Personal Hygiene Behavior Of $4^{\text {Th }}$ Grade Student In Sdn 2 Jambi PS. Banguntapan Bantul. (skripsi). Sekolah Tinggi Ilmu Kesehatan, Aisyiyah Yogyakarta pp.11-40 (2015)

[12] Aziz R, Mangestuti R. The influence of intellectual intelligence, emotional intelligence and spiritual intelligence to aggression in UIN Malang students. El-Qudwah, J Pen \& Pengembangan Vol.1.pp.72 (2006)

[13] Swastiningtyas S, Andreas P, Armasastra: Perbedaan perilaku pemeliharaan kesehatan gigi anak usia \pm 12 tahun antara kelas unggulan dan reguler di MTsN Pagedangan. FKG UI.pp.12-32 (2013)

[14] Shah N, Mathur VP, Kathuria V, Gupta T. Effectiveness of an educational video in improving oral health knowledge in a hospital setting. Indian J Dent Vol.7.pp.70-5 (2016)

[15] Yanti GN, Raphaeli S, Natamihardja L. Perbedaan peningkatan pengetahuan antara metode ceramah dan pemutaran video kartun dalam penyuluhan kesehatan gigi pada siswa kelas II SD Bodhicitta Medan. Dentino J dentistry. Vol. 17.pp.10 (2012)

[16] Hastuti S, Andriyani A. Perbedaan pengaruh pendidikan kesehatan gigi dalam meningkatkan pengetahuan tentang kesehatan gigi pada anak di SD Negeri 2 Sambi Kecamatan Sambi Kabupaten Boyolali. Gaster Vol.7.pp.3 (2010)

[17] Yanti GN, Alamsyah RM, Natassa SE. Effectiveness of dental health education using cartoons video showing method on knowledge and oral hygiene of deaf children in Yayasan Karya Murni Medan. IJADS Vol.3pp.86-90 (2017) 
[18] Thomas OO, Israel OO. Effectiveness of animation and multimedia teaching on students' performance in science subjects. British J of Ed, Soc \& Behavioural Scie Vol.4.pp.201-10 (2014)

[19] Davis, R.L. Short Nutritional Videos and Knowledge Change in A Population of Low Income Individuals in A Community Outreach Setting. Thesis. Ohio: Allied Medical Profession Ohio State University.pp.11-15 (2011)

[20] Susilana R, Riyana C. Media Pembelajaran Hakikat, Pengembangan, Pemanfaatan, dan Penilaian. Bandung: Wacana Prima pp. 9-11 (2009)

[21] Kholid A. Health Promotion with the Approach of Media Behavior Theory and Its Application. Jakarta: Raja Grafindo Persada.pp.120 (2012)

[22] Susanto R. The effect of color exposure on short-term memory retention of primary hypertension sufferers. Jurnal Keperawatan Soedirman. Vol 7.pp.47 (2012)

[23] Iqbal S, Muhammad K. Impact of multimedia-aided teaching on students' academic achievement and attitude at elementary level. US China Educ Rev A Vol.5.pp.349-60 (2015)

[24] Sinor MZ. Comparison between conventional health promotion and use of cartoon animation in delivering oral health education. Int J Human Soc Sci Vol.1.pp.169-74 (2011) 